\title{
THE ROLE OF THE PHARMACIST IN HYPERTENSION MANAGEMENT: A MODEL APPLICATION IN PRIMARY HEALTH CARE
}

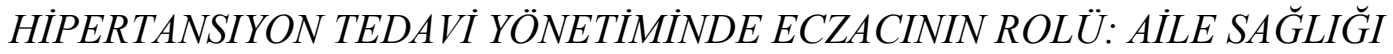 \\ MERKEZI'NDE BIR MODEL UYGULAMASI
}

\begin{abstract}
Aysel PEHLIVANLI ${ }^{1}$ (D), Büşra AKYOL ${ }^{2}$ (D), Özlem SESYILMAZ ${ }^{3}$ (D) Ömer GÖÇÜN ${ }^{4}$ (D) Arzu ONAY BEŞIKCCI ${ }^{2}$ (D), Arif Tanju ÖZÇELİKAY² ${ }^{2}$, Gülbin ÖZÇELİKAY ${ }^{5, *}$

${ }^{1}$ Department of Clinical Pharmacy, Faculty of Pharmacy, Ankara University, Ankara, Turkey

${ }^{2}$ Department of Pharmacology, Faculty of Pharmacy, Ankara University, Ankara, Turkey

${ }^{3}$ Karargahtepe Primary Health Care, Ankara, Turkey

${ }^{4}$ Ayas Primary Health Care, Ankara, Turkey

${ }^{5}$ Department of Pharmacy Management, Faculty of Pharmacy, Ankara University, Ankara, Turkey
\end{abstract}

\section{ABSTRACT}

Objective: Pharmacists have important roles in pharmaceutical care practices. In this study, it was aimed to investigate the potential benefits of the presence of a pharmacist in PHCs (Primary Health Care) in addition to other health care specialists in Ankara Kecioren Karargahtepe PHC and Ankara Ayas PHC.

Material and Method: This study is a quasi-experimental type of study which includes a pre-test and a post-test. Pre-test was given to patients by two pharmacists, which was followed by a basic education on hypertension and its treatment. A post-test was done three months after the pre-test in order to assess the efficiency of the education.

Result and Discussion: In total, 103 patients (70.9\% female; mean age: $62.84 \pm 10.44$ years) were analysed before and after receiving counselling from two pharmacists. The results of pre-and post-tests were analyzed by Wilcoxon t-test using SPSS 23.0. As a result of the statistical analysis, the education provided by the pharmacists enhanced the mean patient scores significantly $(T 0$ (pre-test) $=6(5-7), T 1$ (post-test) $=8(6$ 9); $P<0.05$ ). This study revealed the active role and the requirement of the presence of a pharmacist in addition to other health care providers in PHCs.

Keywords: Hypertension, pharmaceutical care, pharmacist, primary health care

\footnotetext{
* Corresponding Author/Sorumlu Yazar: Gülbin Özçelikay

e-mail / e-posta: gozcelikay@ ankara.edu.tr, Phone / Tel.: +903122033130
} 


\section{ÖZ}

Amaç: Farmasötik bakım uygulamalarında eczacılar önemli rol oynamaktadır. Bu çalışmada Aile Sağliğl Merkezi'nde bulunan diğer să̆lı personellerinin yanı sıra eczacı varlı̆̆ının potansiyel yararları incelenmiştir.

Gereç ve Yöntem: Pre-test ve post-testten oluşan yart-deneysel bir çalışmadır. Hastalara iki ayrı Aile Să̆lı̆̆ Merkezi'nde (Karargahtepe Aile Să̆lı̆̆l Merkezi ve Ayaş Aile Să̆lı̆̆l Merkezi) iki eczacı tarafindan öncelikle pre-test uygulanmış ve sonrasında hipertansiyon tedavi yönetimiyle ilgili eğitim verilmiştir. Üç ay sonrasında verilen eğitimin etkinliğini ölçmek amacıyla post-test uygulanmıştır.

Sonuç ve Tartışma: Toplamda 103 hastaya ulaşılmış ve danışmanlık sağlanmıştır. Genel yaş ortalaması $62.84 \pm 10.44$ olan hastaların \%70.9'unu kadınlar oluşturmaktadır. Sonuçlar, SPSS 23.0. ile Wilcoxon t testi kullanılarak analiz edilmiştir. Verilen eğitimin sonucu olarak post-testte hastaların puanlarının anlamlı olacak

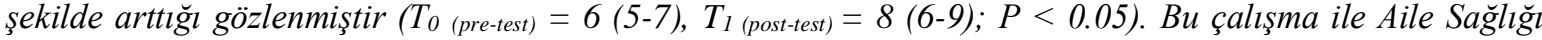
Merkezi'nde diğer sağlık personellerinin yanında eczacının da bulunmasının hipertansiyon hasta yönetimine olumlu katkı sağladiğl gösterilmiştir.

Anahtar Kelimeler: Birinci basamak sağlık merkezi, eczacı, farmasötik bakım, hipertansiyon

\section{INTRODUCTION}

Family medicine specialists provide comprehensive health care services for patients of all ages including the newborns and the elderly. Not only they give advice and guidance about a wide range of health-related matters, but they also defend the patients' rights. In 2004, PHCs have been established as a part of the health transformation program in Turkey. The applications in these facilities were aimed to provide faster solutions for rather simple health conditions without the requirement of specialists or laboratory services. Today, medical doctors, nurses, midwives, health officers and emergency medical assistants are employed in PHCs.

However, with a daily patient profile of 80-100 patients, family medicine specialists face a real difficulty in providing preventive/therapeutic health care that requires a teamwork [1]. As a result, they cannot have sufficient time for patients and rational drug use practices.

As clearly defined by Hepler and Strand as "taking responsibility to improve patient's quality of life", the discussions on the concept of pharmaceutical care have been around since 1990 [2]. Rational drug use (RDU) was defined in Nairobi in 1985 as "receiving medications appropriate to their clinical needs, in doses that meet their own individual requirements, for an adequate period of time, and at the lowest cost to them and their community" [3]. Basic criteria of RDU are: correct indication, correct medication for the correct patient, correct information and follow-up. The first three are followed by medical doctors whereas pharmacists have a significant role in the last two: correct information and follow-up [4].

On th other hand, the number of hypertensive patients is expected to reach 1.5 million by 2025 around the globe. Fifty percent of all deaths are known to be related to hypertension [5]. Hypertension increases the risk of heart disease by $50 \%$ and the risk of stroke by $75 \%$ [6]. Therefore, applications such as pharmaceutical care and RDU are especially important for the management of chronic diseases such as hypertension, thereby improving the quality of life of patients. World Health Organization 
remarks a 50\% role of patient compliance in the control of hypertension [7]. In addition, drug-related problems appear more commonly in elderly patients who should take many drugs (polypharmacy). Specifically, the incidence of adverse drug interactions increases dramatically by $13 \%, 58 \%$, and $82 \%$ when two drugs, five drugs, and eight drugs are used in combination respectively [8]. Studies suggest a positive role of the pharmacists in reducing drug-related problems and improving therapeutic results [9]. Therefore, pharmacists can be beneficial in the management of chronic illness such as hypertension. Indeed, studies suggest a significant role of pharmacists in improving patient compliance and regulation of blood pressure [10,11]. Moreover, many other studies highlight the efficiency of doctor-pharmacist cooperation in the management of hypertension [12-14].

This study was aimed to investigate the potential benefits of pharmacists on the management of hypertension in patients who applied to Ankara Kecioren Karargahtepe PHC and Ankara Ayas PHC.

\section{MATERIAL AND METHOD}

Study design: This study is a quasi-experimental type of study including a pre-test and a posttest. The sample of this study consisted of 103 volunteer patients, outside the period of pregnancy and lactation, aged 18 years and older, who were diagnosed with hypertension and prescribed medications by the family physician, who were admitted to Ankara Kecioren Karargahtepe PHC and Ankara Ayas PHC from 1 June 2017 to 30 November 2017. Ethics Committee approval No. 56786525050.04.04/38678 dated 01/06/2017 of Ankara University was obtained for the research.

Intervention: In the first part of the study, an auxiliary questionnaire for the demographic properties of the patients and a pre-test to measure the knowledge of them about correct blood pressure measurement, what hypertension is and what kind of damage it could do to the other organs in case the blood pressure is not controlled and the importance of the drug they use, regular use of drugs and how to use them, side effects of the drugs, the importance of diet and exercise in controlling hypertension, drug interactions (drug-drug, drug-food and drug-herbal supplements) and storage conditions of drugs by using were applied to patients by using face to face questionnaire method. After that all patients were informed about these issues. Three months after the pre-test, the first questionnaire was re-applied to the same patients as a post-test for the evaluation the effectiveness of the given education.

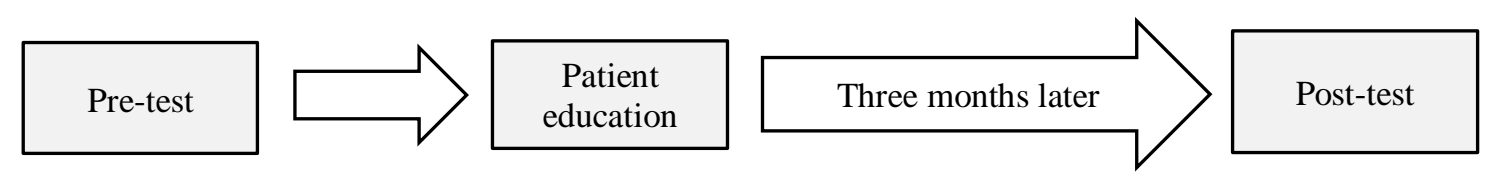

Figure 1. The study process 
Data processing and analysis: For the data analysis, Statistical Package for Social Sciences version 23.0 was used. Kuder-Richardson 20 (KR20) was calculated to assure coefficients of reliability for test. Quantitative data are summarized as mean ( \pm standard deviation) and median; frequency and percentages are presented for qualitative data. Percentages (\%) were used for categorical data. The normal distribution of data of numerical variables was evaluated with Shapiro Wilk test. The data obtained from pre-test and post-test evaluation of the survey questions were analyzed using Wilcoxon $t$ test. $P<0,05$ value was considered statistically significant.

\section{RESULT AND DISCUSSION}

Beginning on 1 June 2017, 51 patients with hypertension from Karargahtepe PHC and 52 patients with hypertension from the Ayas PHC were reached within 1 month. The mean age of the patients was $62.8 \pm 10.4$ years (range: $36-85$ years). Demographic data of the patients is shown in Table 1.

Table 1. Patient demographics.

\begin{tabular}{lll}
\hline Characteristics & N & $\%$ \\
\hline Gender & 30 & 29.1 \\
Male & 73 & 70.9 \\
Female & & \\
Age & 60 & 58.3 \\
$<65$ & 43 & 41.7 \\
$\geq 65$ & & \\
Educational status & 2 & 1.9 \\
Illiterate & 4 & 3.9 \\
Literate & 62 & 60.2 \\
Primary school & 7 & 6.8 \\
Secondary school & 17 & 16.5 \\
High school & 11 & 10.7 \\
University & & \\
& & \\
Body mass index & 1 & 1 \\
Underweight & 13 & 12.6 \\
Normal weight & 43 & 41.7 \\
Overweight & 46 & 44.7 \\
Obese & & 18.4 \\
Smoking & 19 & \\
\hline
\end{tabular}

Most of the patients are obese and overweight which are risk factors for hypertension. In the first part of the study, patients were asked about their characteristics. Data obtained from the patients is shown in Table 2. The vast majority of patients (42.7\%) takes 4-6 drugs per day and 73 patients (70.9\%) are treated with only 1 antihypertensive drug. Most of the patients (68\%) take analgesics when they feel pain. The percentage of the patients who take herbal supplements or dietary supplements is 23.3. Most of the patients visits PHC every three months. Unfortunately, it is shown that a very small amount of the patients $(4.9 \%)$ measures their blood pressure every day. 
Table 2. Patient characteristics

\begin{tabular}{|c|c|c|}
\hline Characteristics & $\mathbf{N}$ & $\%$ \\
\hline Family history & 62 & 59.6 \\
\hline \multicolumn{3}{|l|}{ Duration of illness (years) } \\
\hline $0-5$ & 24 & 23.3 \\
\hline $6-10$ & 30 & 29.1 \\
\hline $11-15$ & 24 & 23.3 \\
\hline 16 and more & 25 & 24.3 \\
\hline \multicolumn{3}{|l|}{ Number of total drugs in use } \\
\hline $1-3$ & 40 & 38.8 \\
\hline $4-6$ & 44 & 42.7 \\
\hline $7-9$ & 15 & 24.6 \\
\hline 10 and more & 4 & 3.9 \\
\hline \multicolumn{3}{|l|}{ Number of antihypertensive drugs in use } \\
\hline 1 & 73 & 70.9 \\
\hline 2 & 28 & 27.2 \\
\hline 3 and more & 2 & 1.9 \\
\hline \multicolumn{3}{|l|}{ Frequency of analgesics use } \\
\hline Every day & 8 & 7.8 \\
\hline When they feel pain & 70 & 68.0 \\
\hline Never & 25 & 24.3 \\
\hline Use of herbal supplements or dietary supplements & 22 & 23.3 \\
\hline \multicolumn{3}{|l|}{ Frequency of visiting the FHC } \\
\hline Every month & 7 & 6.8 \\
\hline Every three months & 64 & 62.1 \\
\hline Not at regular intervals & 32 & 31.1 \\
\hline
\end{tabular}

Additionally, we asked patients about where they received the information on the medications they use. $38.83 \%$ of the patients stated that they received information from their physician, $8.74 \%$ received information from their pharmacist and $42.72 \%$ received information from both their physician and pharmacist, and rest of them $(9,71 \%)$ does not need any information.

A significant number of patients did not know the importance of blood pressure control or why it is important to use drugs; and these patients were using their antihypertensive drug irregularly $(46,6 \%)$.

\section{Evaluation of the Outcome of Education}

A pre-test and post-test consisting of 10 questions was applied to the patients to measure the effectiveness of the training given by pharmacists. The answers of the questions in the test were evaluated as positive ( 1 point) and negative ( 0 point), and the test scores were calculated by summing up the patient's responses. The KR20 value of the test was found to be 0.662 . The training provided by the pharmacists increased the average test scores of the patients thereby eliciting a significant benefit on the patients (Table 3 and Figure 2). 
Table 3. Distribution of the pre-test and post-test scores of patients

\begin{tabular}{ccc}
\hline $\begin{array}{c}\text { Mean pre-test score } \\
\mathbf{T}_{0}\end{array}$ & $\begin{array}{c}\text { Mean post-test score } \\
\mathbf{T}_{1} \\
\text { Median }\end{array}$ & $\mathbf{P}$ \\
\hline $6(5-7)$ & $7(6-9)$ & \\
\hline
\end{tabular}
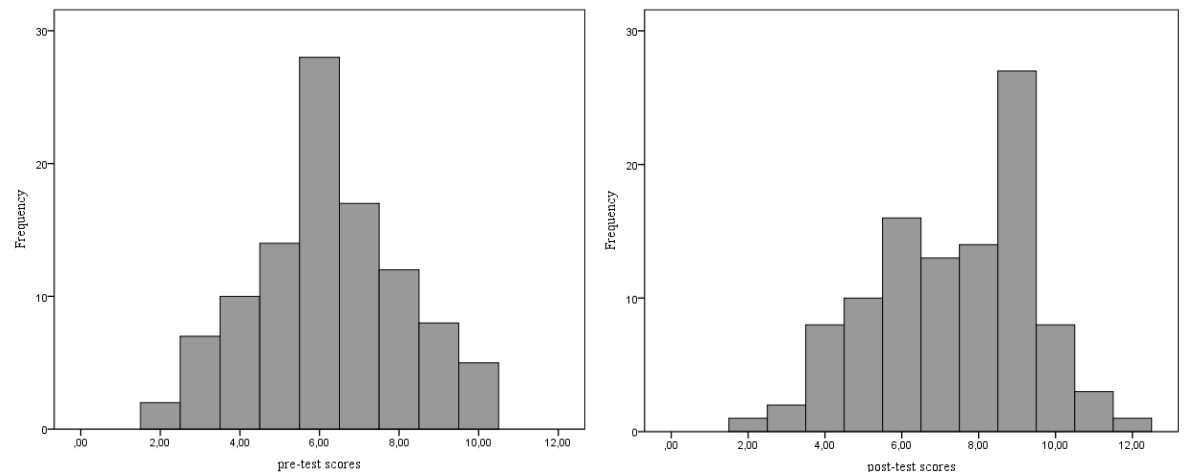

Figure 2. Distribution of the pre-test and post-test scores of patients

Table 4 shows the content of the questions asked to the patients, the mean of the responses given by the patients and the $P$ value which indicates the significance of the training.

Table 4. Questions asked in the pre- and post-tests and the patients' answers.

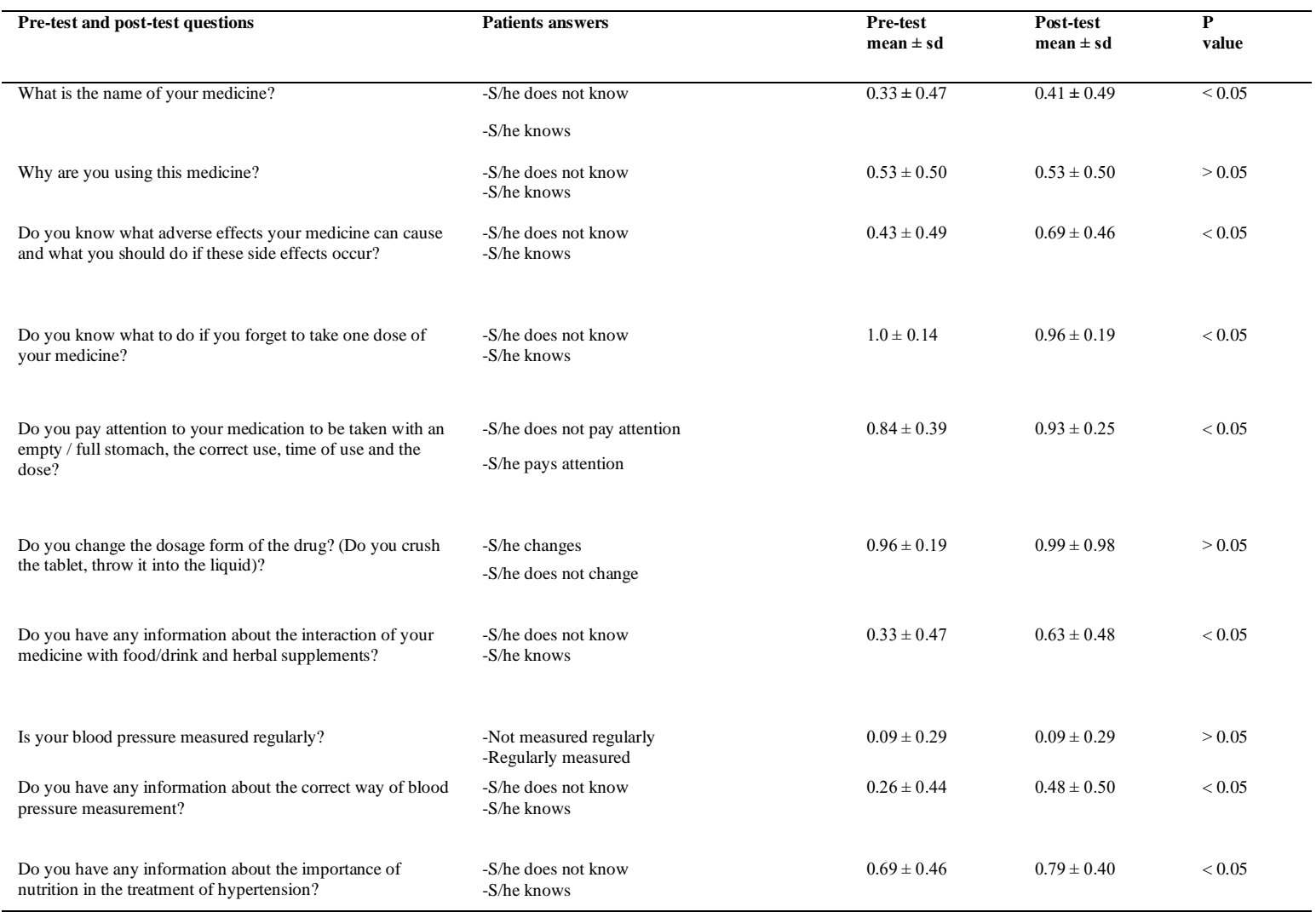


After the education some patients learned the trade names of the drugs $(66 \%$ vs $58.3 \%, P<$ 0.05 ) however it was observed that a significant number of patients did not gain awareness about the importance of using their medication $(P>0.05)$.

Pre-test scores showed that $44.7 \%$ of the patients did not know about adverse drug reactions. After the education this rate dropped to $26.2 \%$ in the post-test $(P<0.05)$.

Patients were told that if they forget to take their medication, they should not take a double dose and if the time of the next dose is too close, then they should continue their routine by taking the next dose. As a result of the training provided, it was seen that the patients gained awareness about this issue $(P<0.05)$.

In the pre-test that was applied, it was observed that the patients did not know about the concept of empty stomach before they were told about the importance of taking their medication with an empty/full stomach and they did not know when the drugs they use should be taken (56.3\%). Patients did not know that hunger meant half an hour/an hour before the meal or 2 hours after the meal. As a result of the education it was observed that the level of their knowledge on this issue has increased significantly after the training $(P<0.05)$.

Most commonly used herbal supplements by the patients were camomile, green tea, rosehip and linden tea. Patients were informed about drug-drug and drug-food interactions; it was clearly recommended that the patients should not use any drugs or herbal supplements without the knowledge of their doctor and pharmacists [15]. The awareness on drugs and food products was also assessed in this study. It increased from $33 \%$ to $62.1 \%$ at pre- and post-tests, respectively $(P<0.05)$.

In the pre-test, it was observed that a significant number of patients did not know the correct blood pressure measurement (73.8\%) and did not measure it regularly (90.3\%). After the education given by pharmacists, it was found that a significant part of the patients learned how to measure it correctly $(P<0.05)$. However, the same effect on the regularity of blood pressure measurement could not be achieved $(P>0.05)$.

Post-test scores on the knowledge about the importance of life style were higher $(82.5 \%)$ compared to the score of the pre-test $(69.9 \%)(P<0.05)$.

An aging population and higher prevalence of chronic diseases lead to increased case complexity and polypharmacy, and consequently greater potential for prescribing errors. Additionally, workload and time pressures exacerbate prescribing errors [17-19].

The increase in chronic diseases necessitates a careful monitoring of community-based disease management programs. Management of a chronic disease includes not only the treatment of the disease but also the knowledge of the patient's self-care abilities [20]. Pharmacists in particular have a significant role in the management of chronic diseases since the patients primarily interact with their 
pharmacists more than other healthcare professionals especially about their drug- and/or disease-related changes [21].

Patients compliance is very important for the treatment of a chronic disease. One of the factors causing a negative impact on patients' compliance is the lack of information about the chronic disease and its treatment. Hypertension is one of the chronic diseases. It increases the risk of heart disease by $50 \%$ and the risk of stroke by $75 \%$ [6]. Therefore, it is important to raise awareness and improve the knowledge of the patients about the efficient blood pressure control and the treatment of hypertension [22].

In the present study, 103 patients with hypertension applying to PHCs were informed about the management of hypertension.

A significant number of patients have learned the correct way of blood pressure measurement (not eating anything or using any medication just before measuring, resting for a while and not talking during the measurement, bringing the arm to the level of heart, being in a sitting position and measuring the blood pressure at the same time daily) which is an important part of the hypertension management [23]. However, it was observed that the same success could not be obtained in regular blood pressure monitoring. The reason for this failure could be due to lack of regular monitoring of blood pressure. We think that it may not be easy for patients to change a permanent habit.

A significant number of patients have gained awareness about drug-food and drug-drug interactions since it was explained the possible risks on the use of any other drugs and herbs without informing the physician or pharmacist may affect the management of the treatment negatively [24]. Additionally, patients have embraced the importance of drug use on empty/full stomach and they have been informed about what kind of adverse effects the hypertensive patients may encounter and importance of consultation with a physician if any adverse effect occurs.

Due to the considerable impact of dietary alterations on blood pressure control [25], additional life style changes such as reducing sodium and increasing potassium intake, limiting alcohol consumption [26] and incorporating vegetables, fruits and reduced fat meat/dairy product [27] were suggested. A significant number of patients have gained awareness about importance of nutrition in the treatment of hypertension.

Interestingly patients could not have awareness about "Why they take their drugs and how to use dosage form of their drugs".

A pharmacist-doctor collaboration contributes to chronic disease management significantly. Several studies have shown that the presence of a pharmacist in PHCs decreases the workload, makes the treatments safer for patients, increases patient satisfaction and provides cost effectiveness especially in cardiovascular disease management such as hypertension $[19,28,29]$. In addition, interventions of pharmacist have potential for a significant impact on blood pressure. However there is considerable 
variability in the extent of the effect in individual studies, meta-analysis suggests a reduction in systolic blood pressure by $7.6 \mathrm{~mm} \mathrm{Hg}$ (95\% CI -9.0 to -6.3 ) and diastolic by $3.9 \mathrm{~mm} \mathrm{Hg}$ (95\% CI -5.1 to -2.8 ) [30].

In another meta-analysis, including 2246 patients from 13 studies, systolic blood pressure was significantly $(\mathrm{P}=0.002)$ reduced by following the pharmacist's intervention, while it remained unchanged in the standard care group $(\mathrm{P}=0.361)$, with a further reduction in systolic blood pressure over controls following pharmacist's intervention $(\mathrm{P}=0.047)$. Medication management $(82 \%)$ and hypertension education (68\%) were the most used interventions [31].

The present study demonstrates a need for the presence of a pharmacist in PHCs in addition to other health care professionals. Employment of a pharmacist for pharmaceutical care at PHCs will be efficient especially for the treatment of chronic diseases and rational drug use.

\section{CONFLICT OF INTEREST}

The authors declare no conflict of interest.

\section{REFERENCES}

1. Türk Eczacıları Birliği. Türkiye'de Aile Hekimliği Uygulamasına Genel Bakış: Türk Eczacıları Birliği Raporu. In: Türkiye'de Aile Hekimliği Uygulamaları ve Serbest Eczacilara Yansımaları 2009. Retrieved June 18, 2018, from http://ekutuphane.teb.org.tr/arsiv.php?anabelge_no=398.

2. Van Mil, J.W., Fernandez-Llimos, F. (2013). What is 'pharmaceutical care' in 2013? Pharm Pract (Granada), 11(1), 1-2.

3. Conference of Experts on the Rational Use of Drugs (1985: Nairobi). (1987). The rational use of drugs: report of the Conference of Experts, Nairobi, 25-29 November 1985. World Health Organization, Retrieved June 18, 2018, from https://apps.who.int/iris/handle/10665/37174.

4. Toklu, H.Z., Dülger, G. (2010). Eczacılar için akılcı ilaç kullanımı eğitimi. Sentez, 6, 16-17.

5. Cazarim, MdS., Freitas, Od., Penaforte, T.R., Achcar, A., Pereira, LRL. (2016). Impact assessment of pharmaceutical care in the management of hypertension and coronary risk factors after discharge. PLoS One, 11(6), e0155204.

6. Kearney, PM., Whelton, M., Reynold, K., Muntner P, Whelton PK, He J. (2005). Global burden of hypertension: analysis of worldwide data. Lancet, 365(9455), 217-223.

7. World Health Organization, 2003. Adherence to long-term therapies: evidence for action / [edited by Eduardo Sabaté]. Retrieved June 18, 2018, from http://www.who.int/iris/handle/10665/42682.

8. Fulton, M.M., Allen, E.R. (2005). Polypharmacy in the elderly: a literature review. J Am Acad Nurse Pract., 17(4), 123-132. 
9. Finkers, F., Maring, J.G., Boersma, F., Taxis, K. (2007). A study of medication reviews to identify drug-related problems of polypharmacy patients in the Dutch nursing home setting. $J$ Clin Pharm Ther., 32(5), 469-476.

10. Morgado, M., Rolo, S., Castelo-Branco, M. (2011). Pharmacist intervention program to enhance hypertension control: a randomised controlled trial. Int J Clin Pharm., 33(1), 132-140.

11. Omboni, S., Sala, E. (2015). The pharmacist and the management of arterial hypertension: the role of blood pressure monitoring and telemonitoring. Expert Rev Cardiovasc Ther., 13(2), 209-221.

12. Green, B.B., Cook, A.J., Ralston, J.D., Fishman, P.A., Catz, S.L., Carlson, J., Carrell, D., Tyll, L., Larson, E.B., Thompson, R.S. (2008). Effectiveness of home blood pressure monitoring, web communication, and pharmacist care on hypertension control: a randomized controlled trial. JAMA, 299(24), 2857-2867.

13. Bogden, P.E., Abbott, R.D., Williamson, P., Onopa, J.K., Koontz, L.M. (1998). Comparing standard care with a physician and pharmacist team approach for uncontrolled hypertension. $J$ Gen Intern Med, 13(11), 740-745.

14. Carter, B.L, Rogers, M., Daly, J., Zheng, S., James, P.A. (2009). The potency of team-based care interventions for hypertension: a meta-analysis. Arch Intern Med., 169(19), 1748-1755.

15. Tachjian, A., Maria, V., Jahangir, A. (2010). Use of herbal products and potential interactions in patients with cardiovascular disease. J Am Coll Cardiol., 55(6), 515-525.

16. American Society of Health System Pharmacists. (1993). ASHP statement on pharmaceutical care. Am J Hosp Pharm., 50, 1720-3.

17. Molokhia, M., Majeed, A. (2017). Current and future perspectives on the management of polypharmacy. BMC Fam Pract., 18, 70.

18. Slight, S.P., Howard, R., Ghaleb, M., Barber, N., Franklin, B.D., Avery, A.J. (2013). The causes of prescribing errors in English general practices: a qualitative study. Br J Gen Pract., 63(615), e713-20.

19. Komwong, D., Greenfield, G., Zaman, H., Majeed, A., Hayhoe, B. (2018). Clinical pharmacists in primary care: a safe solution to the workforce crisis? J R Soc Med., 111(4), 120-124.

20. Incirkus, K., Nahcivan, N.O. (2011). Kronik hastalık bakımını değerlendirme ölçeği-hasta formu'nun Türkçe versiyonunun geçerlik ve güvenirliği. Dokuz Eylül Üniversitesi Hemşirelik Yüksekokulu Elektronik Dergisi, 4(1), 102-109.

21. Adepu, R., Nagavi, B.G. (2006). General practitioners perceptions about the extended roles of the community pharmacists in the state of Karnataka: a study. Indian J Pharm Sci., 68, 36-40.

22. Kara, B., Uzun, S., Yokusoglu, M., Uzun, M. (2009). Hipertansiyon hastalarında ilaç bilgisinin kan basıncını düşürmek için uygulanan yöntemlere etkisi. TAF Preventive Medicine Bulletin, 8(3), 231-238. 
23. Centers for Disease Control and Prevention. CDC 24/7: Saving Lives, Protecting People. Retrieved May 30, 2020, from https://www.cdc.gov/bloodpressure/measure.htm.

24. Tachjian, A., Maria, V., Jahangir, A. (2010). Use of Herbal Products and Potential Interactions in Patients with Cardiovascular Diseases. J Am Coll Cardiol., 55(6), 515-525.

25. O'Shaughnessy, K.M. (2006). Role of diet in hypertension management. Curr Hypertens Rep., 8(4), 292-297.

26. Bazzano, L.A, Green, T., Harrison, T.N., Reynolds, K. (2013). Dietary approaches to prevent hypertension. Curr Hypertens Rep., 15(6), 694-702.

27. Challa, H.J, Uppaluri, K.R. DASH diet (Dietary approaches to stop hypertension). StatPearls. Retrieved May 30, 2020, from https://www.ncbi.nlm.nih.gov/books/NBK482514/.

28. Malet-Larrea, A., Cardenas, V.G, Benito, L.S, Benrimoj, S.I, Calvo, B., Goyenechea, E. (2016). Cost-effectiveness of professional pharmacy services in community pharmacy: a systematic review. Expert Rev Pharmacoecon Outcomes Res., O(ja), null.

29. Polgreen, L.A, Han, J., Carter, B.L., Ardery, G.P., Coffey, C.S., Chrischilles, E.A., James, P.A. (2015). CostEffectiveness of a Physician-Pharmacist Collaboration Intervention to Improve Blood Pressure ControlNovelty and Significance. Hypertension., 66(6), 1145-1151.

30. Santschi, V., Chiolero, A., Colosimo, A.L., Platt, R.W., Taffe, P., Burnier, M., Burnand, B., Paradis, G. (2014). Improving Blood Pressure Control Through Pharmacist Interventions: A Meta-Analysis of Randomized Controlled Trials. J Am Heart Assoc Cardiovasc Cerebrovasc Dis., 3(2), e000718.

31. Machado, M., Bajcar, J., Guzzo, G.C., Einarson, T.R. (2007). Sensivity of patient outcomes to pharmacist interventions. Part II: Systematic review and meta-analysis in hypertension management. Ann Pharmacother, 41, 1770-81. 